\title{
The Establishment of the Evaluation Index of the TQM System of Political Education in the Armed Police Academy
}

\author{
Xiuyuan Peng \\ Logistics University of People's Armed Police Force \\ Tianjin, P.R. China \\ 516763055@qq.com
}

\author{
Jianjun Han \\ Logistics University of People's Armed Police Force \\ Tianjin, P.R. China \\ fmn1992@qq.com
}

\begin{abstract}
The evaluation of the TQM system of the ideological and political education in the Armed Police Academy is an important way of scientific and systematic management of Ideological and political education in Colleges and Universities. It is of great significance to strengthen the construction of Ideological and political education in Colleges and universities, and to promote the scientific progress. In this paper, the fuzzy comprehensive evaluation method is used to construct the comprehensive evaluation system and the membership function of the characteristics of the evaluation, Using analytic hierarchy process (AHP) to calculate the weight of index factors, combination of expert experience and quantitative calculation, the evaluation index of political education benefit in armed police academy is determined. More reasonably solved the problem of the uncertainty and ambiguity in the evaluation of the ideological and political education management system of the grass-roots units. Provides a reference method for the evaluation of the effect of the political education.
\end{abstract}

Keywords-component; armed police forces;colleges and universities; ideological and political education; TQM system, benefit evaluation

\section{CONSTRUCTING THE EVAluATION INDEX OF THE TQM SYSTEM OF POLITICAL EDUCATION IN THE ARMED POLICE ACADEMY}

The performance evaluation system of the TQM system of the ideological and political education in the Armed Police Academy is a system that each evaluation index is different from each other, and the relationship between each other can reflect the overall structure of the TQM system of the ideological and political education. Constructing the performance evaluation index system of the TQM system of the ideological and political education is the core of the performance evaluation of the TQM system in the whole school's ideological and political education.

\section{A. Evaluation Index System Establishment Process}

In this paper, we use the "three level model" to measure the quality of the TQM system of the ideological and political education. It is a three level structure of the overall quality of the TQM system running the whole quality of the decomposition of the different "quality characteristics, quality and quality measurement element", as shown in Figure 1.

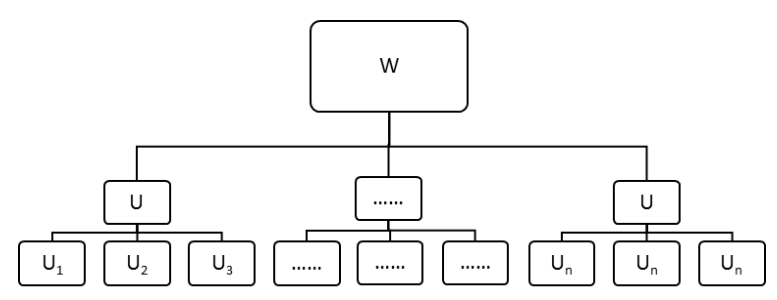

Figure 1.

Some index options are organized according to a certain "three level model" system structure, which constitutes an index system of the quality evaluation of the TQM system of the ideological and political education in Colleges and universities.

\section{B. Structure of Index System}

In this paper, a comprehensive study of the ideas and perspectives, combined with the research, through the discussion and consideration, the general team of Ideological and political education evaluation system design for the three level evaluation index system, as shown in Table 1. 
TABLE I.

\begin{tabular}{|c|c|c|}
\hline Target layer & Index class & Standard layer \\
\hline \multirow{19}{*}{$\begin{array}{l}\text { The } \\
\text { performance } \\
\text { evaluation } \\
\text { index of } \\
\text { TQM } \\
\text { management } \\
\text { system in } \\
\text { political } \\
\text { education in } \\
\text { the Armed } \\
\text { Police } \\
\text { Academy } \\
\text { A }\end{array}$} & \multirow{4}{*}{$\begin{array}{l}\text { Education } \\
\text { quality target } \\
\text { system } \\
\mathrm{B}_{1}\end{array}$} & $\begin{array}{l}\text { The consistency of the educational } \\
\text { objective and the spirit of the higher } \\
\text { level. } C_{11}\end{array}$ \\
\hline & & $\begin{array}{l}\text { The embodiment of the goal of the } \\
\text { political education program and the } \\
\text { rationality of its realization. } C_{12}\end{array}$ \\
\hline & & $\begin{array}{l}\text { Quality objectives for the military } \\
\text { political education of the system of the } \\
\text { provisions of the system. } C_{13}\end{array}$ \\
\hline & & $\begin{array}{l}\text { The specific guidance of quality } \\
\text { objectives for the students' Political } \\
\text { Education. } C_{14}\end{array}$ \\
\hline & \multirow{3}{*}{$\begin{array}{l}\text { Education } \\
\text { quality } \\
\text { management } \\
\text { system } \\
\mathrm{B}_{2}\end{array}$} & $\begin{array}{l}\text { The rationality of Educational } \\
\text { Leadership Organization. } C_{21}\end{array}$ \\
\hline & & $\begin{array}{l}\text { Specific organs and functions of } \\
\text { offices and political education } \\
\text { duties. } C_{22}\end{array}$ \\
\hline & & $\begin{array}{l}\text { The unity and cooperation of the } \\
\text { political education in the } \\
\text { Department. } C_{23}\end{array}$ \\
\hline & \multirow{3}{*}{$\begin{array}{c}\text { Education } \\
\text { quality } \\
\text { evaluation } \\
\text { system } \\
\mathrm{B}_{3}\end{array}$} & $\begin{array}{l}\text { Plan and periodicity of education } \\
\text { effect evaluation. } \mathrm{C}_{31}\end{array}$ \\
\hline & & $\begin{array}{l}\text { The science of education } \\
\text { evaluation. } C_{32}\end{array}$ \\
\hline & & $\begin{array}{l}\text { The evaluation result of education } \\
\text { effect on the promotion of } \\
\text { Education. } \mathrm{C}_{33}\end{array}$ \\
\hline & \multirow{3}{*}{$\begin{array}{c}\text { Education } \\
\text { information } \\
\text { management } \\
\text { system } \\
\mathrm{B}_{4}\end{array}$} & $\begin{array}{l}\text { Classified management of educational } \\
\text { documents. } \mathrm{C}_{41}\end{array}$ \\
\hline & & $\begin{array}{l}\text { The opening and use of education } \\
\text { information network. } C_{42}\end{array}$ \\
\hline & & Register statistics. $\mathrm{C}_{43}$ \\
\hline & \multirow{3}{*}{$\begin{array}{c}\text { Education } \\
\text { quality } \\
\text { statistical } \\
\text { management } \\
\text { technology } \\
\text { B }_{5}\end{array}$} & $\begin{array}{l}\text { Comprehensive rationality of } \\
\text { statistical techniques. } C_{51}\end{array}$ \\
\hline & & $\begin{array}{l}\text { The advanced nature of educational } \\
\text { archives management technology. } \mathrm{C}_{52}\end{array}$ \\
\hline & & $\begin{array}{l}\text { Practical application of educational } \\
\text { information management } \\
\text { technology } C_{53}\end{array}$ \\
\hline & \multirow{3}{*}{$\begin{array}{c}\text { Education } \\
\text { quality } \\
\text { culture } \\
\text { atmosphere } \\
\text { B }_{6}\end{array}$} & $\begin{array}{l}\text { Material level: the modernization and } \\
\text { the supporting of the educational } \\
\text { equipment. } C_{61}\end{array}$ \\
\hline & & $\begin{array}{l}\text { System level: the fairness and justice } \\
\text { of the system of education and } \\
\text { punishment. } C_{62}\end{array}$ \\
\hline & & $\begin{array}{l}\text { Concept: the popularization of the } \\
\text { concept of education quality. } \mathrm{C}_{63}\end{array}$ \\
\hline
\end{tabular}

II. DETERMINE THE WEIGHT OF THE EVALUATION INDEX BY THE ANALYTIC HIERARCHY PROCESS (AHP).

\section{A. The Relative Importance of the "Index Class" and "Standard Layer" by Questionnaire Method}

Because the AHP method is based on the "two two comparison" to establish the judgment matrix, it is used to design the questionnaire.

Through issuing to a college 30 questionnaires, in 30 people to fill in the questionnaire, 5 people are departments of the leadership, 12 people are political education organization members of the authority, 13 people are students team officers and cadets team of Ideological and political education backbone. A total of 30 questionnaires were returned and 27 were valid. The effective rate was $90 \%$. The importance of each factor was scored as a result of four of the number of decimal fractions of the 27 part of the average number of five homes. The questionnaire results of the importance of the factors in the criteria layer:
TABLE II.

\begin{tabular}{|c|c|}
\hline Standard layer factor & Importance scoring \\
\hline \multicolumn{2}{|c|}{ The first category: education target system } \\
\hline $\begin{array}{l}\text { The consistency of the educational objective and } \\
\text { the spirit of the higher level. } C_{11}\end{array}$ & 9 \\
\hline $\begin{array}{l}\text { The embodiment of the goal of the political } \\
\text { education program and the rationality of its } \\
\text { realization. } C_{12}\end{array}$ & 7 \\
\hline 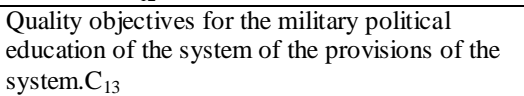 & 3 \\
\hline $\begin{array}{l}\text { The specific guidance of quality objectives for } \\
\text { the students' Political Education. } C_{14}\end{array}$ & 5 \\
\hline \multicolumn{2}{|c|}{ The second category: education quality management system } \\
\hline $\begin{array}{l}\text { The rationality of Educational Leadership } \\
\text { Organization. } \mathrm{C}_{21}\end{array}$ & 9 \\
\hline $\begin{array}{l}\text { Specific organs and functions of offices and } \\
\text { political education duties. } C_{22}\end{array}$ & 5 \\
\hline $\begin{array}{l}\text { The unity and cooperation of the political } \\
\text { education in the Department. } C_{23}\end{array}$ & 8 \\
\hline \multicolumn{2}{|c|}{ Third categories: education quality evaluation system } \\
\hline $\begin{array}{l}\text { Plan and periodicity of education effect } \\
\text { evaluation. } C_{31}\end{array}$ & 7 \\
\hline The science of education evaluation. $\mathrm{C}_{32}$ & 9 \\
\hline $\begin{array}{l}\text { The evaluation result of education effect on the } \\
\text { promotion of Education. } C_{33}\end{array}$ & 3 \\
\hline \multicolumn{2}{|c|}{ Fourth category: education information management system } \\
\hline $\begin{array}{l}\text { Classified management of educational } \\
\text { documents. } C_{41}\end{array}$ & 6 \\
\hline $\begin{array}{l}\text { The opening and use of education information } \\
\text { network. } C_{42}\end{array}$ & 2 \\
\hline Register statistics. $\mathrm{C}_{43}$ & 9 \\
\hline \multicolumn{2}{|c|}{$\begin{array}{c}\text { The fifth kind: the statistical management technology of education } \\
\text { quality }\end{array}$} \\
\hline $\begin{array}{l}\text { Comprehensive rationality of statistical } \\
\text { techniques. } C_{51}\end{array}$ & 2 \\
\hline $\begin{array}{l}\text { The advanced nature of educational archives } \\
\text { management technology. } C_{52}\end{array}$ & 7 \\
\hline $\begin{array}{l}\text { Practical application of educational information } \\
\text { management technology } \mathrm{C}_{53}\end{array}$ & 3 \\
\hline \multicolumn{2}{|c|}{ Sixth categories: education quality and cultural atmosphere } \\
\hline $\begin{array}{l}\text { Material level: the modernization and the } \\
\text { supporting of the educational equipment. } \mathrm{C}_{61}\end{array}$ & 9 \\
\hline $\begin{array}{l}\text { System level: the fairness and justice of the } \\
\text { system of education and punishment. } C_{62}\end{array}$ & 6 \\
\hline $\begin{array}{l}\text { Concept: the popularization of the concept of } \\
\text { education quality. } \mathrm{C}_{63}\end{array}$ & 3 \\
\hline
\end{tabular}

Index of the importance of the factors in the questionnaire survey results:

TABLE III.

\begin{tabular}{|c|c|}
\hline Standard layer factor & $\begin{array}{c}\text { Importance } \\
\text { scoring }\end{array}$ \\
\hline Education quality target system $\mathrm{B}_{1}$ & 9 \\
\hline Education quality management system $\mathrm{B}_{2}$ & 7 \\
\hline Education quality evaluation system $\mathrm{B}_{3}$ & 6 \\
\hline Education information management system $\mathrm{B}_{4}$ & 8 \\
\hline Education quality statistical management technology $\mathrm{B}_{5}$ & 1 \\
\hline Education quality culture atmosphere $\mathrm{B}_{6}$ & 3 \\
\hline
\end{tabular}

\section{B. Structure Judgement Matrix}

Index class layer of the judgment matrix A: 


\begin{tabular}{c|cccccc}
$\mathrm{A}$ & $\mathrm{B}_{1}$ & $\mathrm{~B}_{2}$ & $\mathrm{~B}_{3}$ & $\mathrm{~B}_{4}$ & $\mathrm{~B}_{5}$ & $\mathrm{~B}_{6}$ \\
\hline $\mathrm{B}_{1}$ & 1 & 3 & 4 & 2 & 9 & 7 \\
$\mathrm{~B}_{2}$ & $1 / 3$ & 1 & 2 & $1 / 2$ & 7 & 5 \\
$\mathrm{~B}_{3}$ & $1 / 4$ & $1 / 2$ & 2 & $1 / 3$ & 6 & 4 \\
$\mathrm{~B}_{4}$ & $1 / 2$ & 2 & 3 & 1 & 8 & 6 \\
$\mathrm{~B}_{5}$ & $1 / 9$ & $1 / 7$ & $1 / 6$ & $1 / 9$ & 1 & $1 / 3$ \\
$\mathrm{~B}_{6}$ & $1 / 7$ & $1 / 5$ & $1 / 4$ & $1 / 6$ & 3 & 1
\end{tabular}

The calculation method for matrix $\mathrm{Bij}$ is:

Let $\mathrm{a}=(\mathrm{Bi})-(\mathrm{Bj})$

If $\mathrm{a}>0$, then $\mathrm{Bij}=\mathrm{a}+1$;

If $\mathrm{a}<0$, then $\mathrm{Bij}=1 /(|\mathrm{a}|+1)$.

In this paper, we take $1 \sim 9$ and their reciprocal as scale, and the scale of this paper is shown in Table IV.

TABLE IV.

\begin{tabular}{|c|c|}
\hline Scaling $\mathrm{a}_{\mathrm{ij}}$ & Meaning \\
\hline 1 & Same as before and after \\
\hline 3 & $\begin{array}{l}\text { The former is slightly more important than } \\
\text { the latter }\end{array}$ \\
\hline 5 & The former is more important than the latter \\
\hline 7 & The former is more important than the latter \\
\hline 9 & The former is more important than the latter \\
\hline $2 、 4,6,8$ & $\begin{array}{c}\text { The intermediate value of the two adjacent } \\
\text { levels }\end{array}$ \\
\hline Reciprocal & $\begin{array}{c}\text { The importance of exchange order of two } \\
\text { elements }\end{array}$ \\
\hline
\end{tabular}

Any judgment matrix should be satisfied with $\mathrm{Bij}=1$ or $\mathrm{Bji}=1 / \mathrm{Bij}$. And so on, correlation matrix B1, each criterion layer B2, B3, B4, B5, B6 respectively as follows:

$\mathrm{B}_{1}$

\begin{tabular}{c|cccc} 
& $\mathrm{C}_{11}$ & $\mathrm{C}_{12}$ & $\mathrm{C}_{13}$ & $\mathrm{C}_{14}$ \\
\hline $\mathrm{C}_{11}$ & 1 & 3 & 7 & 5 \\
$\mathrm{C}_{12}$ & $1 / 3$ & 1 & 5 & 3 \\
$\mathrm{C}_{13}$ & $1 / 7$ & $1 / 5$ & 1 & $1 / 3$ \\
$\mathrm{C}_{14}$ & $1 / 5$ & $1 / 3$ & 3 & 1
\end{tabular}

$\mathrm{B}_{2}$

\begin{tabular}{c|ccc} 
& $C_{21}$ & $C_{22}$ & $C_{23}$ \\
\hline$C_{21}$ & 1 & 3 & $1 / 2$ \\
$C_{22}$ & $1 / 3$ & 1 & $1 / 4$ \\
$C_{23}$ & 2 & 4 & 1
\end{tabular}

$\mathrm{B}_{3}$

\begin{tabular}{c|ccc} 
& $C_{31}$ & $C_{32}$ & $C_{33}$ \\
\hline$C_{31}$ & 1 & $1 / 3$ & 5 \\
$C_{32}$ & 3 & 1 & 7 \\
$C_{33}$ & 5 & $1 / 7$ & 1
\end{tabular}

$\mathrm{B}_{4}$

\begin{tabular}{c|ccc} 
& $\mathrm{C}_{41}$ & $\mathrm{C}_{42}$ & $\mathrm{C}_{43}$ \\
\hline $\mathrm{C}_{41}$ & 1 & 5 & $1 / 4$ \\
$\mathrm{C}_{42}$ & $1 / 5$ & 1 & $1 / 8$ \\
$\mathrm{C}_{43}$ & 4 & 8 & 1
\end{tabular}

$\mathrm{B}_{5}$

\begin{tabular}{c|ccc} 
& $C_{51}$ & $C_{52}$ & $C_{53}$ \\
\hline$C_{51}$ & 1 & $1 / 6$ & $1 / 2$ \\
$C_{52}$ & 6 & 1 & 5 \\
$C_{53}$ & 2 & $1 / 5$ & 1
\end{tabular}

$\mathrm{B}_{6}$

\begin{tabular}{c|ccc} 
& $\mathrm{C}_{61}$ & $\mathrm{C}_{62}$ & $\mathrm{C}_{63}$ \\
\hline $\mathrm{C}_{61}$ & 1 & 4 & 7 \\
$\mathrm{C}_{62}$ & $1 / 4$ & 1 & 4 \\
$\mathrm{C}_{63}$ & $1 / 7$ & $1 / 4$ & 1
\end{tabular}

\section{Calculate the Weight of Each Index}

In the next step, it is necessary to determine the weight of each index in the sub system which is determined by the matrix, and it is necessary to carry out the consistency test to ensure the relative importance of each index.

The weights of the indexes are calculated in the subsystem. A matrix:

First calculate the product of each line:

$\mathrm{Mi}=\prod_{j=1}^{n} A_{i j}, \quad M=((1512,35 / 3,1,144,1 / 9072,1 / 280)$

The calculation of M n $(\mathrm{n}=6) \operatorname{root} \overline{W_{1}}=\sqrt[n]{M_{\mathrm{i}}}$

$\overline{W_{1}}=(3.388,1.560,1,2.289,0.219,0.391)$

To treat the $\bar{W}$, the characteristic vector of $\mathrm{W}$ :

$W_{i}=\frac{\overline{W_{1}}}{\sum_{i=1}^{n} \bar{W}_{j}}, W=(0.377,0.176,0.113,0.259,0.025,0.050)$

$\mathrm{W}_{\mathrm{i}}$ is the weight of $\mathrm{B}_{\mathrm{i}}$ in $\mathrm{A}$, that is, the weight of the target system is 0.377, the weight of the quality management system is 0.176 , the weight of the quality evaluation system is 0.259 , the weight of the information management system is 0.113 , the weight of the educational quality is 0.025 , the weight of the quality culture atmosphere is 0.50 .

\section{Absolute Weight of Criteria Layer Index}

The above $\mathrm{W}$ is under a level relative to the upper level of the weight and the index layer "judgment matrix $\mathrm{B}_{1}, \mathrm{~B}_{2}, \mathrm{~B}_{3}, \mathrm{~B}_{4}, \mathrm{~B}_{5}, \mathrm{~B}_{6}$ and the corresponding vector of each component is multiplied by" target "judgment matrix a corresponding to the component value can be.

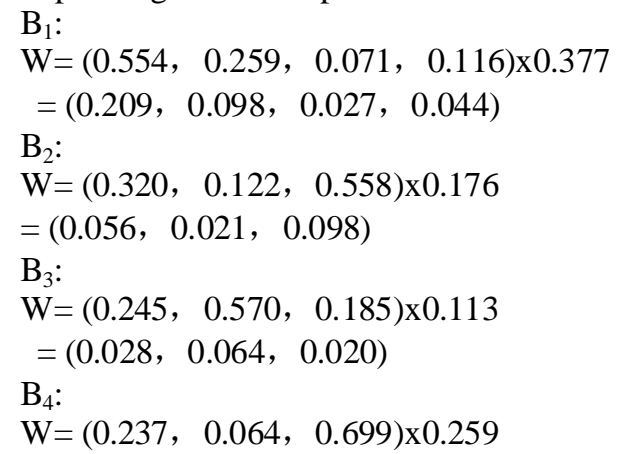




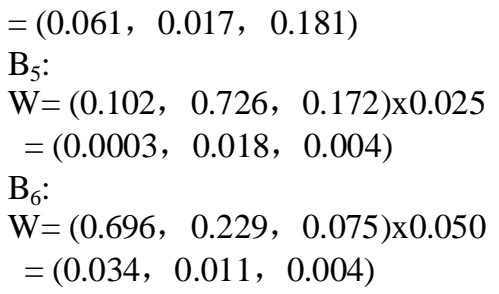

\section{E. Comment Set}

Evaluation set is the evaluation of each factor, the general $\mathrm{p}=1,2, \ldots \mathrm{N}$ as the evaluation value arithmetic sequence. According to common sense, generally take the $1,2,3,4,5$ five levels, the corresponding comments are very poor, poor, the general, good, very good".

\section{EVAluAtion OF THE MEMBERS OF THE EXPERT GROUP}

The joint evaluation expert group is composed of the TQM system construction of the ideological and political education, the organization of the implementation of the organization and the educated. Set up the leadership of the evaluation of the $E 1$, the organization for the implementation of the evaluation for E2, the education evaluation of E3, here also can be used in this paper to assess the importance of two two, and then use the AHP method to calculate the weight of the three.

Due to the organization and implementation, including organ in the ideological and political education TQM system operation staff, students team officers, ideological and political education backbone, is a more direct understanding of the practical operation of the system as a whole and maintenance, the most familiar to the system as a whole, understand the, so the system may be problems, there may be insufficient, so in the importance of the design, the column in the first place.

The leader of the system of Ideological and political education is the actual head of the army, the global problem of the troops has a more accurate grasp, you can stand in the global perspective to examine the operation of the TQM system of Ideological and political education, so in the importance of design, it is listed in the second.

Ideological and political education is the education of the students is the education of the direct audience, the quality of education has a direct understanding of the. But because it is the evaluation of the establishment of the TQM system, and the education of students only know the education effect, but it is not clear that the specific content of the TQM system, which reflects the effect of Ideological and political education has important reference value, but in the system construction is not significant. So, to put its importance in the final.

In this, we simplify the scale, 1 the importance of the two is the same, 2 the former is more important than the latter, 3 said that the former is obviously important, and the reciprocal of the exchange order of importance. According to the operating rules of the system, the expert group can be considered as the $\mathrm{E}$ :

\begin{tabular}{c|ccc} 
& $E_{1}$ & $E_{2}$ & $E_{3}$ \\
\hline$E_{1}$ & 1 & $1 / 2$ & 2 \\
$E_{2}$ & 2 & 1 & 3 \\
$E_{3}$ & $1 / 2$ & $1 / 3$ & 1
\end{tabular}

$\mathrm{M}=(1,6,1 / 6)$

$\mathrm{W}=(0.297,0.540,0.163)$

According to the actual situation, the number of the group of experts is generally 20 people, then:

The number of leading group members is 6; The number of organizations in the implementation is 11; The number of people being educated is 3 .

\section{CAlCUlation of All Kinds of Evaluation VALUES}

\section{A. Single factor evaluation matrix}

Taking the quality objective layer $\mathrm{B}_{1}$ as an example, the weight of each criterion layer factor is $\mathrm{C}_{1 \mathrm{j}}=$ $(0.141,0.081,0.044,0.044)$, and the evaluation of the 4 elements of the expert evaluation in the evaluation set $(1,2,3,4,5)$ of the percentage of the composition of the matrix is:

$$
R_{1}=\left[\begin{array}{lllll}
r_{11} & r_{12} & r_{1 a} & r_{14} & r_{15} \\
r_{21} & r_{22} & r_{2 a} & r_{24} & r_{25} \\
r_{a 1} & r_{a 2} & r_{a a} & r_{a 4} & r_{a 5} \\
r_{d 1} & r_{d 2} & r_{d a} & r_{d 4} & r_{d 5}
\end{array}\right]
$$

$r_{i j}$ is the percentage of the total number of experts who have played by $\mathrm{i}$ in the $\mathrm{j}$ of $\mathrm{B}_{1}$ in all the experts. Therefore, $R_{1}$ is the single factor fuzzy evaluation matrix of $B_{1}$. The single factor fuzzy evaluation matrix can be got for B2,B3,B4,B5,B6.

\section{B. Evaluation Index}

The method for evaluating the Bi of the index class $\mathrm{Vi}$ is:

$$
\mathrm{V}_{\mathrm{i}}=\mathrm{W}_{\mathrm{i}} \text { 。 } \quad \mathrm{R}_{\mathrm{i}} \text { 。 } \quad\left(\begin{array}{lllll}
1 & 2 & 3 & 4 & 5
\end{array}\right)^{\mathrm{T}}
$$

$W_{i}$ is a membership matrix of index $R_{i}$, and $B_{i}$ is a matrix of the percentage of each element of the $B_{i}$ criteria layer. The evaluation matrix can reflect the overall operation of this kind of index, and it is more macro than the single factor evaluation results, and can be used to evaluate the operation of the TQM system of Ideological and political education.

\section{Comprehensive Evaluation Value}

To this step, the comprehensive evaluation of the value of the calculation is more easily, and the calculation formula:

$$
V=\sum_{i=1}^{19} W_{i}^{a} P_{i}
$$

$W_{\mathrm{i}}^{\mathrm{s}}$ is the absolute weight of the i element of the rule layer, the $\mathrm{P}_{\mathrm{i}}$ is the average of the 20 experts to give an evaluation of this element. The result is the performance evaluation of the design and operation of the TQM system of the ideological and political education of the troops, the results are excellent between $4-5,3-4$ is good, and 2-3 is the general, 3 and the following needs to be improved. When the score is 3 , we should analyze the evaluation value of the index class, find out the index which has a low 
score, and analyze the factors which affect the efficiency of the system.

\section{PRACTICAL SignificANCE OF All KindS OF EVALUATION VALUES}

\section{A. Comprehensive Evaluation Value}

Comprehensive evaluation value is a reflection of the operation of the TQM system in the first phase of the ideological and political education in Colleges and universities. The TQM system of the ideological and political education is compared. If the comprehensive evaluation value is higher than in the past, the operation of the system tends to be improved. Otherwise, the system will be deteriorated and the operation of the system should be improved.

\section{B. Evaluation Index}

The evaluation value of the index is compared with the various components of the TQM system of the ideological and political education. This comparison is helpful to the head of the Party committee to understand the ideological and political education of the TQM system in the general situation of the operation of the unit, which aspects of the operation is better, what aspects need to be improved, and in the future decision-making and funding to those in urgent need to improve the direction of tilt.

\section{Single factor evaluation matrix}

The single factor evaluation matrix completely preserved the proportion of the expert group on the evaluation of each criterion layer factor, which directly reflects the operating conditions of the TQM system. After the comprehensive evaluation value of the TQM system of the ideological and political education, the organization and operation of the system to check the single factor evaluation matrix, will be the basic factors of the score, to find out the factors that affect the comprehensive evaluation of the larger and lower scores, and proposed improvement plan, submitted to the Party Committee for approval. In this way, through the TQM system of Ideological and political education in the periodic evaluation, will continue to find out the shortcomings and deficiencies in the construction system, and to improve the TQM system to improve the ideological and political education.

\section{CONCLUSIONS}

Due to the limitation of space and individual level, and the comprehensive quality management, the depth and breadth of this paper is very limited, and can not carry out more, deeper and more effective research. But I hope the door knocking grassroots Army Ideological and political education quality system management, to play a valuable role, the more knowledgeable and interested and experienced people began this research, I believe will make the grass-roots army ideological and political education quality management is a leap in the progress.

\section{REFERENCES}

[1] Li Junkui and Wang Shengzhen, Analysis of the Related Concepts of Ideological and Political Education [J], Research on Ideological and Political Education, 2012, 02:27-29.

[2] Luo Yuting, The essence of Ideological and political education is to grasp the masses [J], Marx's study, 2012,09:128-137+160.

[3] Hong Dapeng and Dong Cheng, Strengthen the network ideological and political education theory seminar held in Nanjing [J], Research on the theory of military political work, 2012,03:2.

[4] Li Yanmei, The application of TQM in the experimental teaching management in Colleges and Universities [J], Experimental science and technology, 2014,02:130-133..

[5] Yang Mingwei, On the quality and efficiency of the military ideological and political education resources development and utilization under the Cultural Perspective $[\mathrm{J}]$, Research on Ideological and Political Education, 2014,04:137-140.

[6] Liu Ning, On the benefit view of the ideological and political work in the new period $[\mathrm{J}]$, Technology rich guide, 2012,17:335.

[7] Tian Hang, On the current situation and Countermeasures of the construction of the style of study in the Armed Police Academy [J], Theory,2013,02:177-178.

[8] $\mathrm{Li} \mathrm{Li}$, The Enlightenment of the theory of demand on improving the benefit of military thought and Politics Education [J], The theory, 2013,06:20-21.

[9] Li Wen and Yu Hongli, TQM evaluation index system of college teaching based on Balanced Score Card [J], Journal of Zhejiang University of Technology (SOCIAL SCIENCE EDITION), 2011,04:427-431.

[10] Gao Zhu, Study on the ideological and political education of armed police forces [D], Changchun University of Science and Technology, 2013.

[11] Wu Dongsheng, The relationship between Ideological and political education and civic education[J], Journal of Ideological and theoretical education, 2013,04:107-111.

[12] Wang Sicong, Research on strengthening the ideological and political education of soldiers in Armed Police Forces [D], Jilin University of Finance and Economics, 2013. 